Article

\title{
The Origin of Major Ions of Groundwater in a Loess Aquifer
}

\author{
Tianming Huang $1,2, * \mathbb{D}$ and Baoqiang $\mathrm{Ma}^{3}$ \\ 1 Key Laboratory of Shale Gas and Geoengineering, Institute of Geology and Geophysics, Chinese Academy \\ of Sciences, Beijing 100029, China \\ 2 College of Earth and Planetary Sciences, University of Chinese Academy of Sciences, Beijing 100049, China \\ 3 College of Geoscience and Surveying Engineering, China University of Mining \& Technology, \\ Beijing 100083, China; zqt1700203063g@student.cumtb.edu.cn \\ * Correspondence: tmhuang@mail.iggcas.ac.cn; Tel.: +86-10-8299-8276
}

Received: 26 October 2019; Accepted: 22 November 2019; Published: 23 November 2019

check for updates

\begin{abstract}
When groundwater represents most of the world's reserves of unfrozen freshwaters, water quality is commonly a limiting factor in quantifying usable fresh groundwater storage, especially in arid and semi-arid areas. Tracing the origin of major ions is important to the understanding of hydrochemical evolution and water-rock interaction. Strontium (Sr) and calcium (Ca) are geochemically similar in terms of ionic radius and ionic charge and can substitute for each other in mineral lattices such as in carbonates and silicates. This allows the use of $\mathrm{Sr}$ as a proxy for Ca during water-rock interaction. Geochemical mass balance and carbon and strontium isotope techniques were employed to study the origin of each major ion (such as $\mathrm{Na}, \mathrm{Ca}, \mathrm{Mg}, \mathrm{Cl}$, and $\mathrm{SO}_{4}$ ) in a loess aquifer (there is $10 \%$ to $20 \%$ of carbonate in the loess). Geochemical mass balance between atmospheric deposition and groundwater shows that the $\mathrm{Cl}$ (average concentration of $5.5 \mathrm{mg} / \mathrm{L}$ ) and $\mathrm{SO}_{4}$ (average concentration of $6.8 \mathrm{mg} / \mathrm{L}$ ) in groundwater originated from atmospheric deposition. The dissolution of loess using acetic acid was used to analyze the ${ }^{87} \mathrm{Sr} /{ }^{86} \mathrm{Sr}$ ratio of carbonate (mainly deposited in continental environments). Groundwater ${ }^{87} \mathrm{Sr} /{ }^{86} \mathrm{Sr}$ ratios (0.710677 to 0.712319$)$ are consistent with ${ }^{87} \mathrm{Sr} /{ }^{86} \mathrm{Sr}$ ratios in carbonate ( 0.710329 to 0.711085$)$ but are significantly lower than the whole-rock ( 0.715136 to 0.717155 ) and residue ( 0.719091 to 0.720438 ), suggesting that $\mathrm{Ca}$ and $\mathrm{Mg}$ mainly originated from the dissolution of carbonate in the loess aquifer. However, Na originated from the dissolution of albite, suggesting saturation controls the ability of dissolution. There are cation exchanges between $\mathrm{Ca}+\mathrm{Mg}$ and $\mathrm{Na}$, resulting in $\mathrm{Na}$ concentration increases and $\mathrm{Ca}+\mathrm{Mg}$ concentration decreases in groundwater. This study is important to the understand of the origin of the major ions in groundwater and the geochemical processes in silicate-carbonate aquifers.
\end{abstract}

Keywords: groundwater; strontium; isotopes; geochemical methods; acetic acid; ${ }^{87} \mathrm{Sr} /{ }^{86} \mathrm{Sr}$

\section{Introduction}

Groundwater represents about $96 \%$ of the world's reserves of unfrozen freshwaters [1]. Groundwater is of fundamental significance for human development to meet the rapidly expanding urban, industrial, and agricultural water requirements, especially in arid and semi-arid areas [2], and more than two billion people in the world depend on groundwater for their daily supply [3]. Meanwhile, water quality is a limiting factor for usable fresh groundwater utilization [4,5]. Poor water quality can be caused by a natural condition (such as strong aridity or many soluble salts in an aquifer) and by human activities (such as fertilizer utilization and drainage of waste waters). The impact of human activities on water quality were only recognized in the past half-century before which time, pristine conditions reflecting natural processes controlled the hydrochemistry [6]. The impact 
of diffuse pollution from intensive agriculture, waste disposal, and point source pollution from urban and industrial sources, relied on geochemistry to solve questions of origin and attenuation. In semi-arid regions facing water scarcity, geochemical approaches have been vital in the assessment of renewability [6,7] and characterizing water-rock interaction.

The $\mathrm{Cl}, \mathrm{SO}_{4}, \mathrm{HCO}_{3} / \mathrm{CO}_{3}, \mathrm{Na}, \mathrm{K}, \mathrm{Ca}$, and $\mathrm{Mg}$ are the major ions in groundwaters $[4,8]$, which reflect the geochemical evolution and water-rock interaction. Their sources vary from different sites and become more complex when they are affected by human intervention. Strontium $(\mathrm{Sr})$ and calcium (Ca) are geochemically similar in terms of ionic radius and ionic charge and can substitute for each other in mineral lattices such as in carbonates and some silicates [9]. Therefore, Sr has been used as a proxy for Ca in many studies [10-12]. In most cases, carbonate rocks have higher contents of strontium but lower ${ }^{87} \mathrm{Sr} /{ }^{86} \mathrm{Sr}$ as compared to strontium derived from silicate rocks with lower contents of strontium and higher ${ }^{87} \mathrm{Sr} /{ }^{86} \mathrm{Sr}[12,13]$. Marine carbonate commonly has a ${ }^{87} \mathrm{Sr} /{ }^{86} \mathrm{Sr}$ value that is less than 0.709 [12]. The difference in ${ }^{87} \mathrm{Sr} /{ }^{86} \mathrm{Sr}$ makes it possible to identify the water-rock interaction from carbonate or silicate. For example, based on the ${ }^{87} \mathrm{Sr} /{ }^{86} \mathrm{Sr}$, the chemical composition of the Wujiang River (Guizhou Province, SW China) waters are characterized mainly by limestone weathering, while those of the adjacent Qingshuijiang River waters are characterized mainly by dolomite and silicate weathering [14]. The pore waters extracted from the matrix from the Cretaceous Chalk of southern England were intermediate between the calcite matrix (acetic acid soluble, low ${ }^{87} \mathrm{Sr} /{ }^{86} \mathrm{Sr}$ ratios) and clay component (high ${ }^{87} \mathrm{Sr} /{ }^{86} \mathrm{Sr}$ ratios), suggesting groundwater is strongly influenced by the weathering or exchange with clays [15].

Most studies over the world have focused on carbonates deposited in marine environments in aquifers and the ${ }^{87} \mathrm{Sr} /{ }^{86} \mathrm{Sr}$ ratios for the marine carbonates have been well constructed $[12,15]$. However, for carbonates deposited in continental environments, the ${ }^{87} \mathrm{Sr} /{ }^{86} \mathrm{Sr}$ ratios [16-18] and $\delta^{13} \mathrm{C}$ values vary largely [19-21] because of changes in deposition environments. This study aims to determine the origin of the major ions in the Xifeng loess aquifer, in NW China, mainly using major ion chemistry and C isotopes along with $\mathrm{Sr}$ isotopes to study the natural geochemical processes for groundwater. The calcites in the loess were deposited in continental environments (i.e., loessification) $[22,23]$. The aquifer was chosen for several reasons which include: (1) there are typically $10 \%$ to $20 \%$ carbonate in loess [22,24], presenting a relatively complex matrix of aquifer; (2) the hydrogeological condition is relatively simple and the groundwater cycle has been well recognized [21,25]; and (3) groundwaters are all old water [21], presenting a natural groundwater quality level with little human interference. The chemical (temperature, $\mathrm{EC}, \mathrm{pH}$, TDS, $\mathrm{Cl}, \mathrm{SO}_{4}, \mathrm{NO}_{3}, \mathrm{HCO}_{3}, \mathrm{~F}, \mathrm{Br}, \mathrm{Na}, \mathrm{K}, \mathrm{Ca}$, and $\mathrm{Mg}$ ) and isotopic composition $\left(\delta^{2} \mathrm{H}-\mathrm{H}_{2} \mathrm{O}, \delta^{18} \mathrm{O}-\mathrm{H}_{2} \mathrm{O}, \delta^{15} \mathrm{~N}-\mathrm{NO}_{3}, \delta^{18} \mathrm{O}-\mathrm{NO}_{3}, \delta^{13} \mathrm{C}-\mathrm{DIC},{ }^{3} \mathrm{H}\right.$, and $\left.{ }^{14} \mathrm{C}-\mathrm{DIC}\right)$ of groundwater and isotopic composition $\left(\delta^{13} \mathrm{C}\right.$ and $\left.\delta^{18} \mathrm{O}\right)$ of carbonate of loess have been reported in our previous study [21]. In this study, we further analyzed $\mathrm{Sr}$ concentration and ${ }^{87} \mathrm{Sr} /{ }^{86} \mathrm{Sr}$ in groundwater samples, and ${ }^{87} \mathrm{Sr} /{ }^{86} \mathrm{Sr}$ in loess as whole-rock and conducted dissolution experiment using acetic acid to determine the ${ }^{87} \mathrm{Sr} /{ }^{86} \mathrm{Sr}$ ratios of carbonate in loess.

\section{Study Area and Sampling}

The Xifeng loess tableland is located in the central part of the Loess Plateau of China (LPC) and is the largest tableland in the LPC with a loess depth of 150 to $200 \mathrm{~m}$ [25]. The horizontal Cretaceous mudstone $\left(K_{1} l h\right)$ is covered by Quaternary loess (Figure 1$)$ composed of lower Pleistocene $\left(Q_{1}\right)$, middle Pleistocene $\left(Q_{2}\right)$, and upper Pleistocene $\left(Q_{3}\right)$ deposits. The $Q_{1}$ Loess, with a thickness of 40 to $50 \mathrm{~m}$, commonly crops out at the bottom of the upper and middle reaches of gullies. The hard and compacted $\mathrm{Q}_{1}$ Loess has low permeability and is usually considered as an aquitard [25]. The $\mathrm{Q}_{2}$ Loess has a thickness of 120 to $170 \mathrm{~m}$ and commonly crops out on the sides of valleys and at the heads and cliffs of gullies. The $\mathrm{Q}_{2}$ Loess is unconsolidated and has relatively large porosity and is considered to be a good aquifer. The $\mathrm{Q}_{3}$ Loess has a thickness of 10 to $15 \mathrm{~m}$ and is distributed above the $\mathrm{Q}_{2}$ Loess as the topsoil in the area (Figure 1). 

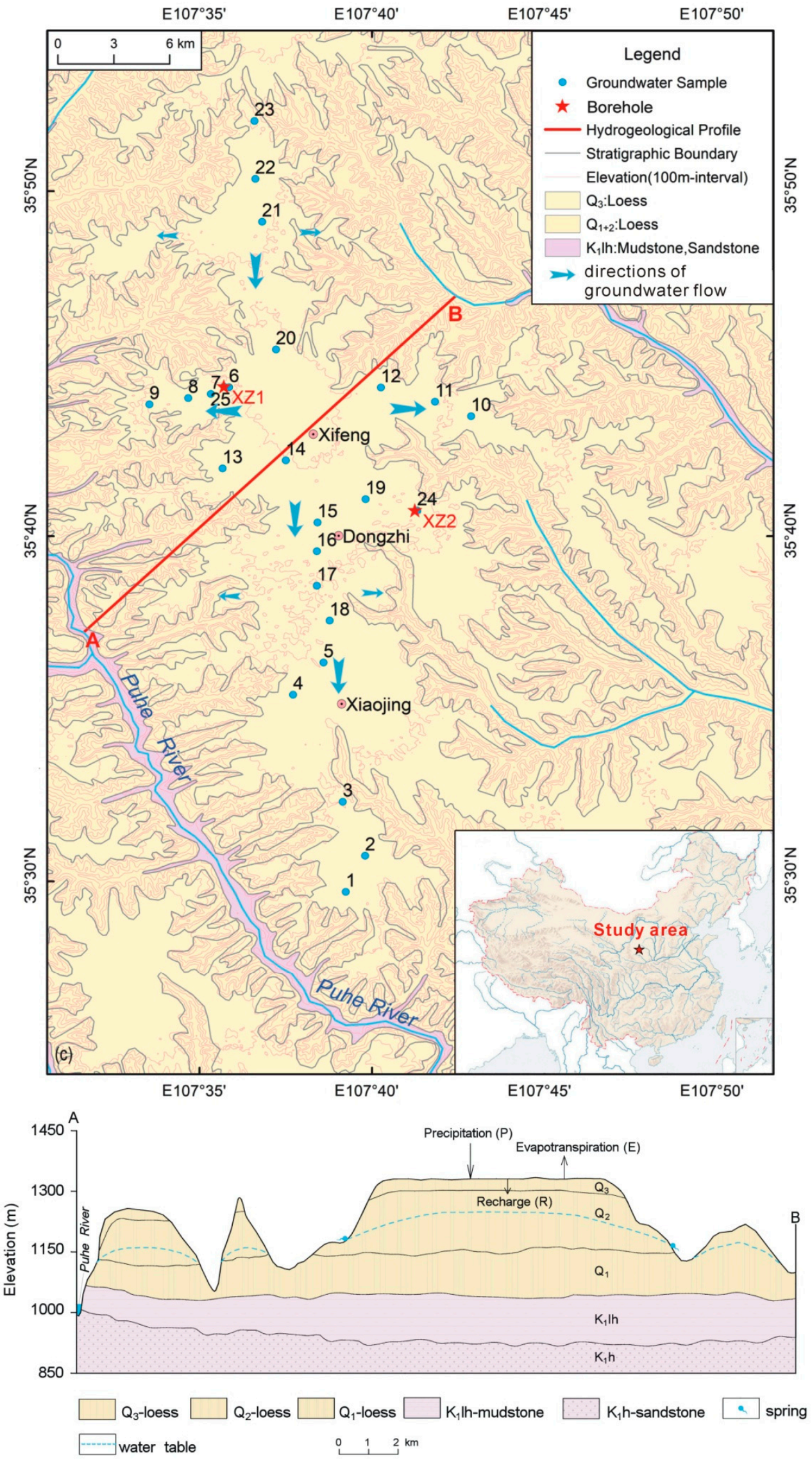

Figure 1. The hydrogeological condition of the study area and sampling location modified from [21]. 
The depth of the water table is in the range of 40-75 $\mathrm{m}$ with an increasing trend from the center of the plain to its surrounding areas. The discharge of groundwater is mainly in the form of suspension gravity springs in gullies (Figure 1). The average annual precipitation is $546 \mathrm{~mm} /$ year, approximately $68 \%$ of which falls between June and September during the Asian monsoon. The average annual temperature is $9.2^{\circ} \mathrm{C}$ according to data reported from 1956 to 2010 . The main crops are winter wheat and maize, with one crop each per year.

According to our recent study [21], diffuse recharge through the thick unsaturated zone is the only recharge source to the aquifer. The recent infiltrated recharging water, since the 1950s, is still retained in the upper $10 \mathrm{~m}$ of the unsaturated zone with a recharge rate in the range of $37-41 \mathrm{~mm} /$ year. Therefore, the groundwater is all old water (tritium free) with the corrected ${ }^{14} \mathrm{C}$ ages in the range of $220-19,220$ years.

Twenty-six shallow groundwater samples, with well depths in the range of 55-180 m, were sampled in 2018 (Figure 1). Meanwhile, loess samples were collected from two deep profiles (XZ1 with a depth of $55 \mathrm{~m}$ and XZ2 with a depth of $45 \mathrm{~m}$ ) by using an engineering geological survey drill. There were no fluids added during drilling. The bulk samples of $\sim 2000 \mathrm{~g}$ were collected, at $0.25 \mathrm{~m}$ intervals at 0 to $20 \mathrm{~m}$ and $0.50 \mathrm{~m}$ intervals below $20 \mathrm{~m}$ ( 280 samples in total). The samples were immediately sealed in polyethylene bags after collection.

\section{Experiment and Analyses}

In this study, we further analyzed the following: (1) Sr concentration $(\mathrm{n}=26)$ and ${ }^{87} \mathrm{Sr} /{ }^{86} \mathrm{Sr}(\mathrm{n}=14)$ in groundwater samples and $(2){ }^{87} \mathrm{Sr} /{ }^{86} \mathrm{Sr}(\mathrm{n}=10)$ in loess as whole-rock and conducted a dissolution experiment using acetic acid (HAc) with different concentrations $(0.5 \mathrm{M}$ and $1 \mathrm{M})$ to determine the ${ }^{87} \mathrm{Sr} /{ }^{86} \mathrm{Sr}$ ratios of carbonate in loess.

The 0.5 M HAc can only dissolve calcite $\left(\mathrm{CaCO}_{3}\right)$ and magnesite $\left(\mathrm{MgCO}_{3}\right)$, and $1 \mathrm{M} \mathrm{HAc}$ can dissolve dolomite $\left(\mathrm{CaMg}\left(\mathrm{CO}_{3}\right)_{2}\right)[17,18,26]$. The $\mathrm{HCl}$ was not used because it can dissolve some silicates $[17,26,27]$. Four loess samples (unsaturated zone sample, S1 and S2; saturated zone sample, S3 and S4) were chosen to conduct the dissolution experiment. First, mineral and geochemical compositions were analyzed. Then, $400 \mathrm{~mL}$ of $0.5-\mathrm{M}$ HAc was added into $40 \mathrm{~g}$ of dried loess. The samples were agitated intermittently for $4 \mathrm{~h}$, and the supernatant solution was centrifuged and filtered through $0.45 \mu \mathrm{m}$ filters for $\mathrm{Sr}$, major cation, and ${ }^{87} \mathrm{Sr} /{ }^{86} \mathrm{Sr}$ analyses. The residual loess was dried and $150 \mathrm{~mL}$ of 1-M HAc was added into $15 \mathrm{~g}$ of dried residual loess. The samples were also agitated intermittently for $4 \mathrm{~h}$, and the supernatant solution was centrifuged and filtered through $0.45 \mu \mathrm{m}$ filters for $\mathrm{Sr}$, major cation, and ${ }^{87} \mathrm{Sr} /{ }^{86} \mathrm{Sr}$ analyses. The residual loess after dissolution by $1 \mathrm{M}$ of HAc was dried for mineral composition and ${ }^{87} \mathrm{Sr} /{ }^{86} \mathrm{Sr}$ analyses.

The mineral composition was analyzed using an X-ray diffraction system (XRD) (X'Pert Pro, Malvern Panalytical Ltd., Malvern, UK). The major elements were analyzed using an X-ray fluorescence spectrometer (XRF) (Axios-mAX, Malvern Panalytical Ltd., Malvern, UK). Major cation (Na, K, Ca, and $\mathrm{Mg}$ ) was analyzed using an inductively coupled plasma optical emission spectrometry (ICP-OES) (5300DV, Perkin Elmer, Waltham, MA, USA) and Sr was analyzed using an inductively coupled plasma mass spectrometry (ICP-MS) (NexION 300D, Perkin Elmer, Waltham, MA, USA). The ${ }^{87} \mathrm{Sr} /{ }^{86} \mathrm{Sr}$ ratio was measured using a multi-collector thermal ionization mass spectrometry (TIMS) (Finnigan MAT 261, Thermo Scientific, Waltham, MA, USA), which gave a ratio of $0.710235 \pm 0.000026$ for the NIST NBS 987 standard. All the analyses were conducted at the Beijing Research Institute of Uranium Geology.

\section{Results}

\subsection{Geochemical Characteristics of Loess}

Loess is a kind of aeolian deposit and has been deposited in succession since 2.4 Ma [22]. Under different deposition environments (such as temperature and precipitation), particle sizes and geochemical compositions for loess with different ages change but with limited variations $[19,22]$. 
The loess samples in this study contain a significant proportion of silt-sized particles ( 2 to $50 \mu \mathrm{m})$, accounting for $70 \%$ to $84 \%$, and less clay $(<2 \mu \mathrm{m}$ and $<12 \%)$ and sand $(>50 \mu \mathrm{m}$ and $\sim 12 \%)$. Loess is composed of quartz, potassium feldspar, plagioclase, clay, and carbonate (calcite and dolomite) (Table 1). The illite-smectite, illite, kaolinite, and chlorite are the main components for clay (Table 2). The loess samples are enriched in carbonate ranging from 9.1\% to $22.1 \%$ (Table 1 ). The $\mathrm{CaCO}_{3}$ in loess mainly originated from secondary deposit (accounting for 90\%) that occurs during the loessification processes $[17,22-24,28]$. Secondary carbonates originate from the vertical, horizontal, or in situ resettlement of carbonates during pedogenesis in the soil-sedimentary environment [28]. Table 3 shows the element composition for the four loess samples.

Table 1. The mineral composition for loess (\%).

\begin{tabular}{ccccccc}
\hline Sample & Quartz & Potassium Feldspar & Plagioclase & Calcite & Dolomite & Clay \\
\hline S1 & 43.0 & 3.4 & 16.5 & 9.1 & 0.0 & 28.0 \\
S2 & 44.7 & 2.9 & 11.8 & 13.6 & 0.0 & 27.0 \\
S3 & 44.5 & 4.3 & 15.3 & 16.4 & 3.4 & 16.1 \\
S4 & 33.1 & 2.8 & 9.8 & 22.1 & 0.0 & 32.2 \\
\hline
\end{tabular}

Table 2. The mineral composition for clay in loess (\%).

\begin{tabular}{cccccc}
\hline Sample & Smectite & Illite-Smectite & Illite & Kaolinite & Chlorite \\
\hline S1 & 0 & 32 & 49 & 5 & 14 \\
S2 & 0 & 20 & 60 & 7 & 13 \\
S3 & 0 & 21 & 58 & 9 & 12 \\
S4 & 0 & 13 & 68 & 7 & 12 \\
\hline
\end{tabular}

Table 3. Major element content for loess samples (\%). LOI, loss on ignition.

\begin{tabular}{cccccccccccc}
\hline Sample & $\mathrm{SiO}_{\mathbf{2}}$ & $\mathrm{Al}_{\mathbf{2}} \mathbf{O}_{\mathbf{3}}$ & $\mathrm{Fe}_{\mathbf{2}} \mathbf{O}_{\mathbf{3}}$ & $\mathbf{M g O}$ & $\mathbf{C a O}$ & $\mathbf{N a}_{\mathbf{2}} \mathbf{O}$ & $\mathbf{K}_{\mathbf{2}} \mathbf{O}$ & $\mathbf{M n O}$ & $\mathrm{TiO}_{\mathbf{2}}$ & $\mathbf{P}_{\mathbf{2}} \mathrm{O}_{\mathbf{5}}$ & $\mathbf{L O I}$ \\
\hline $\mathrm{S} 1$ & 59.14 & 12.02 & 4.51 & 2.11 & 7.05 & 1.78 & 2.34 & 0.087 & 0.649 & 0.141 & 9.77 \\
$\mathrm{~S} 2$ & 58.98 & 12.56 & 4.89 & 2.05 & 6.36 & 1.58 & 2.38 & 0.087 & 0.677 & 0.139 & 9.72 \\
$\mathrm{~S} 3$ & 59.51 & 11.83 & 4.35 & 2.15 & 7.28 & 1.72 & 2.28 & 0.083 & 0.637 & 0.167 & 9.79 \\
$\mathrm{~S} 4$ & 54.73 & 11.89 & 4.57 & 1.95 & 9.42 & 1.39 & 2.26 & 0.085 & 0.636 & 0.204 & 12.37 \\
\hline
\end{tabular}

The carbon isotopic composition $\left(\delta^{13} \mathrm{C}\right)$ for marine carbonate is $0.6 \%$ o $\pm 1.6 \%$ [29] and it typically ranges from $-10 \%$ o to $-2 \%$ o for continental carbonate [20] with an average value of $-4.9 \% \pm 2.8 \%$ o [29] . The $\delta^{13} \mathrm{C}$ values for carbonate in loess in the study area range from $-8.3 \%$ o to $-3.3 \%$ (Table 4 ), showing the continental origin of the carbonate. The values are consistent with that in the Luochuan tableland ranging from $-9 \%$ o to $-4 \%$ o [23].

Table 4. Isotopic compositions for loess in Xifeng. The values of $\delta^{13} \mathrm{C}$ are from [21].

\begin{tabular}{cccc}
\hline Location & Depth Range $(\mathbf{m})$ & $\boldsymbol{\delta}^{\mathbf{1 3}} \mathbf{C}(\mathbf{\% o})$ & ${ }^{87} \mathbf{S r} /{ }^{86} \mathbf{S r}$ \\
\hline XZ1 & $9.75-10(\mathrm{~S} 1)$ & -6.8 & 0.715481 \\
XZ1 & $19.75-20$ & -4.8 & 0.715244 \\
XZ1 & $29.5-30(\mathrm{~S} 2)$ & -6.9 & 0.716614 \\
XZ1 & $39.5-40$ & -5.2 & 0.715639 \\
XZ1 & $52-52.5$ & -5.8 & 0.715851 \\
XZ1 & $54.5-55(\mathrm{~S} 3)$ & -3.3 & 0.715873 \\
XZ2 & $9.75-10$ & -8.3 & 0.716586 \\
XZ2 & $19.75-20$ & -5.7 & 0.715136 \\
XZ2 & $29.5-30$ & -5.2 & 0.717155 \\
XZ2 & $44.5-45(S 4)$ & -7.2 & 0.716909 \\
\hline
\end{tabular}


The strontium isotopic composition $\left({ }^{87} \mathrm{Sr} /{ }^{86} \mathrm{Sr}\right)$ for the whole loess ranges from 0.715136 to 0.717155 (Table 4). Because the whole loess includes silicate, evaporite (if there was), and carbonate minerals, the values are the mixed results for the two kinds of minerals.

\subsection{Hydrogeochemical Characteristics of Groundwater}

The groundwater is fresh water with TDS ranging from 225 to $316 \mathrm{mg} / \mathrm{L}$ with an average value of $288 \mathrm{mg} / \mathrm{L}$ (Table 5). There is no tritium detected and the corrected ${ }^{14} \mathrm{C}$ age ranges from 220 to 19,220 years [21], suggesting that groundwaters are all old water with little influence from human activities. The $\mathrm{Cl}_{\text {and }} \mathrm{SO}_{4}$ concentrations are rather low, with an average value of $5.5 \mathrm{mg} / \mathrm{L}$ and $6.8 \mathrm{mg} / \mathrm{L}$, respectively. The main anion is $\mathrm{HCO}_{3}(91.4 \%)$ and the main cations are Ca $(40.4 \%), \mathrm{Mg}(31.7 \%)$, and $\mathrm{Na}(27.5 \%)$ (Figure 2). The saturation indices (SI) calculated by using Phreeqc software [30] for calcite $\left(S I_{\text {cal }}\right)$ and dolomite $\left(S I_{\mathrm{dol}}\right)$ are all larger than zero, suggesting groundwaters are all over-saturated with respect to calcite and dolomite. The SI values for fluorite, gypsum, magnesite, and strontianite are less than zero, suggesting that groundwaters are all under-saturated with respect to these minerals (Table 5).

Groundwater ${ }^{87} \mathrm{Sr} /{ }^{86} \mathrm{Sr}$ values range from 0.710677 to 0.712319 with an average of 0.711207 (Table 5), significantly lower than the ${ }^{87} \mathrm{Sr} /{ }^{86} \mathrm{Sr}$ values of the whole loess (0.715136 to 0.717155$)$. Groundwater $\delta^{13} \mathrm{C}$ values show very limited variation from $-9.6 \%$ o to $-8.1 \%$ o (Table 5 ).

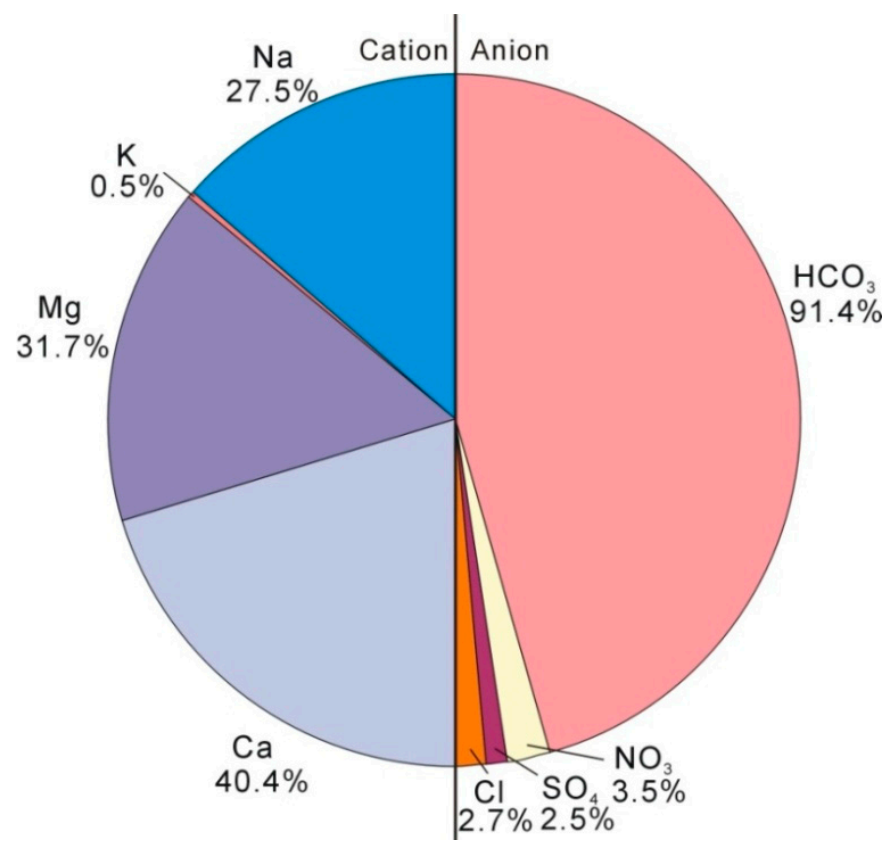

Figure 2. The ions composition (\% in meq/L) for groundwater.

Table 5. Hydrogeochemical and strontium isotopic composition for groundwater. The values labeled with * are from [21].

\begin{tabular}{cccccc}
\hline Item & Unit & Min. & Max. & Average & Median \\
\hline $\mathrm{TDS}^{*}$ & $\mathrm{mg} / \mathrm{L}$ & 225 & 316 & 288 & 289 \\
$\mathrm{pH}^{*}$ & - & 7.6 & 8.2 & 7.9 & 7.8 \\
$\mathrm{Cl}^{*}$ & $\mathrm{mg} / \mathrm{L}$ & 4.0 & 10.9 & 5.5 & 5.3 \\
$\mathrm{SO}_{4}{ }^{*}$ & $\mathrm{mg} / \mathrm{L}$ & 3.2 & 13.1 & 6.8 & 6.9 \\
$\mathrm{NO}_{3}{ }^{*}$ & $\mathrm{mg} / \mathrm{L}$ & 6.5 & 19.2 & 12.4 & 11.9 \\
$\mathrm{HCO}_{3}{ }^{*}$ & $\mathrm{mg} / \mathrm{L}$ & 246 & 357 & 322 & 324 \\
$\mathrm{~F}^{*}$ & $\mathrm{mg} / \mathrm{L}$ & 0.3 & 0.6 & 0.4 & 0.4 \\
$\mathrm{Br}$ & $\mathrm{mg} / \mathrm{L}$ & 0.019 & 0.029 & 0.025 & 0.027 \\
$\mathrm{Na}{ }^{*}$ & $\mathrm{mg} / \mathrm{L}$ & 18 & 84 & 35 & 28 \\
\hline
\end{tabular}


Table 5. Cont.

\begin{tabular}{cccccc}
\hline Item & Unit & Min. & Max. & Average & Median \\
\hline $\mathrm{K}^{*}$ & $\mathrm{mg} / \mathrm{L}$ & 0.5 & 1.8 & 1.0 & 1.0 \\
$\mathrm{Mg}^{*}$ & $\mathrm{mg} / \mathrm{L}$ & 11 & 28 & 21 & 23 \\
$\mathrm{Ca}^{*}$ & $\mathrm{mg} / \mathrm{L}$ & 22 & 56 & 45 & 49 \\
$\delta^{13} \mathrm{C}^{\mathrm{DIC}}{ }^{*}$ & $\%$ o & -9.6 & -8.1 & -8.7 & -8.7 \\
${ }^{3} \mathrm{H}^{*}$ & $\mathrm{TU}$ & $<0.4$ & $<0.4$ & $<0.4$ & $<0.4$ \\
${ }^{14} \mathrm{C}$ age & years & 220 & 19220 & 9990 & 12424 \\
& calcite & 0.20 & 0.83 & 0.44 & 0.43 \\
& dolomite & 0.36 & 1.67 & 0.83 & 0.78 \\
saturation indices & fluorite & -2.14 & -1.65 & -1.90 & -1.91 \\
$(\mathrm{SI})$ & gypsum & -3.47 & -2.59 & -2.97 & -2.90 \\
& magnesite & -0.41 & 0.26 & -0.17 & -0.21 \\
& strontianite & -1.44 & -0.62 & -1.04 & -1.03 \\
$\mathrm{Sr}$ & mg/L & 0.278 & 0.646 & 0.489 & 0.516 \\
${ }^{87} \mathrm{Sr} /{ }^{86} \mathrm{Sr}$ & - & 0.710677 & 0.712319 & 0.711207 & 0.711157 \\
\hline
\end{tabular}

\subsection{Characteristics of Carbonate in Loess}

Because only $\mathrm{CaCO}_{3}$ and $\mathrm{MgCO}_{3}$ can be dissolved in the $0.5 \mathrm{M}$ acetic acid (HAc) $[17,26]$, the $\mathrm{CaCO}_{3}$ and $\mathrm{MgCO}_{3}$ content in loess can be calculated. The results show that during the dissolution processes using $0.5 \mathrm{M}$ of $\mathrm{HAc}$, there is plenty of Ca dissolved, with the concentration ranging from $5260 \mathrm{mg} / \mathrm{L}$ to $7445 \mathrm{mg} / \mathrm{L}$, however, the $\mathrm{Mg}$ concentration is relatively limited (127 to $161 \mathrm{mg} / \mathrm{L}$ ). Here, we have not considered the limited desorption process on the clay surface.

The content of $\mathrm{CaCO}_{3}$ in loess, calculated using the $\mathrm{HAc}$ dissolution experiment, ranges from $13.15 \%$ to $18.61 \%$ (Table 6 ), and overlaps with the results $(9.1 \%$ to $22.1 \%)$ from the XRD analyses (Table 1). The $\mathrm{MgCO}_{3}$ content in loess ranges from $0.44 \%$ to $0.56 \%$ (Table 6), much lower than $\mathrm{CaCO}_{3}$. The $\mathrm{Sr}$ concentration ranges from $5.1 \mathrm{mg} / \mathrm{L}$ to $8.3 \mathrm{mg} / \mathrm{L}$, and ${ }^{87} \mathrm{Sr} /{ }^{86} \mathrm{Sr}$ ranges from 0.710455 to 0.711085 .

The dolomite $\left(\mathrm{CaMg}\left(\mathrm{CO}_{3}\right)_{2}\right)$ can be dissolved in $1 \mathrm{M}$ of HAc [26]. The $\mathrm{Mg}$ concentration ranged from $72 \mathrm{mg} / \mathrm{L}$ to $219 \mathrm{mg} / \mathrm{L}$. The dolomite content in the whole loess ranges from $0.47 \%$ to $1.43 \%$ (Table 6 ). The ${ }^{87} \mathrm{Sr} /{ }^{86} \mathrm{Sr}$ ratios in the solution of $1 \mathrm{M}$ of HAc range from 0.710329 to 0.710969 , close to the ${ }^{87} \mathrm{Sr} /{ }^{86} \mathrm{Sr}$ ratios in the $0.5 \mathrm{M}$ of HAc solution (0.710455 to 0.711085$)$, suggesting little silicate dissolution for $1 \mathrm{M}$ of HAc dissolution.

After dissolution by $1 \mathrm{M}$ of HAc, there is no carbonate in the loess and the residual minerals are mainly silicates (Table 7). The residual minerals have high ${ }^{87} \mathrm{Sr} /{ }^{86} \mathrm{Sr}$ ratios, ranging from 0.719091 to 0.720438 (Table 7).

Table 6. The results for loess dissolution using HAc (-1:40 g soil and $400 \mathrm{~mL} \mathrm{0.5} \mathrm{M} \mathrm{of} \mathrm{HAc;}-2: 15 \mathrm{~g}$ residual soil and $150 \mathrm{~mL} 1 \mathrm{M}$ of $\mathrm{HAc})$.

\begin{tabular}{|c|c|c|c|c|c|c|c|c|c|}
\hline Sample & $\begin{array}{c}\mathrm{Ca} \\
\mathrm{mg} / \mathrm{L}\end{array}$ & $\begin{array}{c}\mathrm{Mg} \\
\mathrm{mg} / \mathrm{L}\end{array}$ & $\begin{array}{c}\mathrm{Na} \\
\mathrm{mg} / \mathrm{L}\end{array}$ & $\begin{array}{c}\mathrm{K} \\
\mathrm{mg} / \mathrm{L}\end{array}$ & $\begin{array}{c}\mathrm{Sr} \\
\mu \mathrm{g} / \mathrm{L}\end{array}$ & ${ }^{87} \mathrm{Sr} /{ }^{86} \mathrm{Sr}$ & $\begin{array}{c}\mathrm{CaCO}_{3} \\
(\%)\end{array}$ & $\underset{(\%)}{\mathrm{MgCO}_{3}}$ & $\underset{(\%)}{\mathrm{CaMg}\left(\mathrm{CO}_{3}\right)_{2}}$ \\
\hline S1-1 & 5870 & 161 & 11.7 & 3.7 & 8304 & 0.710750 & \multirow{2}{*}{14.68} & \multirow{2}{*}{0.56} & \multirow{2}{*}{0.76} \\
\hline S1-2 & 485 & 117 & 8.7 & 4.4 & 785 & 0.710818 & & & \\
\hline S2-1 & 5260 & 147 & 12.4 & 4.0 & 6394 & 0.711038 & \multirow{2}{*}{13.15} & \multirow{2}{*}{0.51} & \multirow{2}{*}{0.48} \\
\hline S2-2 & 406 & 72 & 8.2 & 4.2 & 683 & 0.710969 & & & \\
\hline S3-1 & 5770 & 127 & 11.9 & 5.1 & 8081 & 0.710455 & \multirow{2}{*}{14.43} & \multirow{2}{*}{0.44} & \multirow{2}{*}{1.43} \\
\hline S3-2 & 691 & 219 & 8.2 & 4.3 & 896 & 0.710329 & & & \\
\hline S4-1 & 7445 & 128 & 12.7 & 5.5 & 5111 & 0.711085 & \multirow{2}{*}{18.61} & \multirow{2}{*}{0.45} & \multirow[b]{2}{*}{0.47} \\
\hline S4-2 & 1034 & 76 & 8.4 & 6.0 & 996 & 0.710958 & & & \\
\hline
\end{tabular}


Table 7. The mineral composition and ${ }^{87} \mathrm{Sr} /{ }^{86} \mathrm{Sr}$ ratios for residual loess after $1 \mathrm{M}$ of HAc dissolution.

\begin{tabular}{cccccccc}
\hline Sample & Quartz & Potassium Feldspar & Plagioclase & Calcite & Dolomite & Clay & ${ }^{87} \mathbf{S r} /{ }^{86} \mathbf{S r}$ \\
\hline S1-res & 51.2 & 4.0 & 19.2 & 0 & 0 & 25.6 & 0.719091 \\
S2-res & 54.9 & 2.6 & 13.4 & 0 & 0 & 29.1 & 0.720415 \\
S3-res & 53.5 & 1.9 & 16.2 & 0 & 0 & 28.4 & 0.719876 \\
S4-res & 54.0 & 2.2 & 11.8 & 0 & 0 & 32.0 & 0.720438 \\
\hline
\end{tabular}

\section{Discussion}

\subsection{Atmospheric Deposition}

Chloride is one of the most conservative tracers in the water cycle. It seldom substitutes into minerals and only precipitates at very high concentrations [31]. It does not significantly participate in oxidation and reduction reactions [32]. Chloride is commonly used to estimate groundwater recharge based on the mass balance between $\mathrm{Cl}$ from atmospheric deposition and $\mathrm{Cl}$ in soil water [33,34], or between $\mathrm{Cl}$ from atmospheric deposition and $\mathrm{Cl}$ in groundwater $[35,36]$. Chloride in groundwater, in the study area, originated from atmospheric deposition based on that $\mathrm{Br} / \mathrm{Cl}$ values (0.0034 to 0.0061 ) for groundwater are equal to or exceed the marine-derived precipitation of $0.0034[37,38]$. This is a reasonable assumption in well-drained soil [33,39,40]. Feth [41] also reported that where groundwater contains less than $10 \mathrm{mg} / \mathrm{L}$ chloride, atmospheric sources are probably the major source (the average $\mathrm{Cl}$ concentration in groundwater is $5.5 \mathrm{mg} / \mathrm{L}$ ). Therefore, we can use $\mathrm{Cl}$ to estimate the atmospheric deposition amount for a specific ion.

On the basis of the chemical observation of precipitation in the adjacent Jiwozi station, from 2000 to 2015 [42], which is about $220 \mathrm{~km}$ from the study area, the weighted average concentration of $\mathrm{Cl}$, $\mathrm{SO}_{4}, \mathrm{Na}, \mathrm{Ca}$, and $\mathrm{Mg}$ are $1.13 \mathrm{mg} / \mathrm{L}, 8.63 \mathrm{mg} / \mathrm{L}, 1.59 \mathrm{mg} / \mathrm{L}, 6.08 \mathrm{mg} / \mathrm{L}$, and $0.67 \mathrm{mg} / \mathrm{L}$, respectively. The atmospheric deposition amount can be calculated using the enrichment factor based on the $\mathrm{Cl}$ concentration between precipitation and groundwater. For example, when the groundwater $\mathrm{Cl}$ concentration is $5.7 \mathrm{mg} / \mathrm{L}$, the enrichment factor between groundwater and precipitation would be 5 (i.e., $5.7 \mathrm{mg} / \mathrm{L}$ of groundwater divided by $1.13 \mathrm{mg} / \mathrm{L}$ of precipitation), and then, the atmospheric deposition amount for $\mathrm{SO}_{4}$ is expected to be $5 \times 8.63 \mathrm{mg} / \mathrm{L}=43.2 \mathrm{mg} / \mathrm{L}$. If the $\mathrm{SO}_{4}$ concentration in groundwater is larger than $43.2 \mathrm{mg} / \mathrm{L}$ it suggests that there are other $\mathrm{SO}_{4}$ sources, whereas a concentration less than $43.2 \mathrm{mg} / \mathrm{L}$ suggests that the atmospheric deposition can explain the existence of $\mathrm{SO}_{4}$ in groundwater.

The results show that enrichment factor in the study area ranges from 3.5 to 9.6 and the estimated atmospheric deposition for $\mathrm{SO}_{4}$ ranges from $30.2 \mathrm{mg} / \mathrm{L}(3.5 \times 8.63 \mathrm{mg} / \mathrm{L})$ to $82.8 \mathrm{mg} / \mathrm{L}(9.6 \times 8.63 \mathrm{mg} / \mathrm{L})$, while $\mathrm{SO}_{4}$ in groundwater is only $3.2-13.1 \mathrm{mg} / \mathrm{L}$, suggesting groundwater $\mathrm{SO}_{4}$ originated from atmospheric deposition. The estimated values are very high, mainly caused by the high concentration in modern precipitation affected by human activities, such as $\mathrm{SO}_{2}$ emission $[43,44]$. Because there are no sulfur minerals (such as gypsum and pyrite) in the loess, and loess is well-drained soil, the origin from an atmospheric deposition for groundwater $\mathrm{SO}_{4}$ is, therefore, reasonable. However, for the $\mathrm{Na}$, $\mathrm{Ca}$, and $\mathrm{Mg}$, the estimated atmospheric deposition is significantly lower than those in groundwater, suggesting there are other sources for them.

\subsection{The Origin of $\mathrm{Na}, \mathrm{Ca}$, and $\mathrm{Mg}$}

When precipitation infiltrates through the unsaturated zone to recharge groundwater, soil $\mathrm{CO}_{2}$ is dissolved in soil water, making soil water weakly acid. The weakly acid soil water could further dissolve minerals to produce $\mathrm{Na}, \mathrm{Ca}$, and $\mathrm{Mg}[8,37]$.

The Na concentration in groundwater ranges from $18 \mathrm{mg} / \mathrm{L}$ to $84 \mathrm{mg} / \mathrm{L}$ with an average value of $35 \mathrm{mg} / \mathrm{L}$, larger than the concentration in $0.5 \mathrm{M}$ of HAc dissolution (11.7 to $12.7 \mathrm{mg} / \mathrm{L})$. This suggests that $\mathrm{Na}$ originated from the dissolution of albite.

$$
2 \mathrm{NaAlSi}_{3} \mathrm{O}_{8}+11 \mathrm{H}_{2} \mathrm{O}+2 \mathrm{CO}_{2} \rightarrow \mathrm{Al}_{2} \mathrm{Si}_{2} \mathrm{O}_{5}(\mathrm{OH})_{4}+2 \mathrm{Na}^{+}+2 \mathrm{HCO}_{3}{ }^{-}+4 \mathrm{H}_{4} \mathrm{SiO}_{4}
$$


Because there is carbonate in loess, $\mathrm{CO}_{2}$ would also dissolve carbonate.

$$
\begin{gathered}
\mathrm{CaCO}_{3}+\mathrm{H}_{2} \mathrm{O}+\mathrm{CO}_{2} \rightarrow \mathrm{Ca}^{2+}+2 \mathrm{HCO}_{3}{ }^{-} \\
\mathrm{MgCO}_{3}+\mathrm{H}_{2} \mathrm{O}+\mathrm{CO}_{2} \rightarrow \mathrm{Mg}^{2+}+2 \mathrm{HCO}_{3}{ }^{-} \\
\mathrm{CaMg}\left(\mathrm{CO}_{3}\right)_{2}+2 \mathrm{H}_{2} \mathrm{O}+2 \mathrm{CO}_{2} \rightarrow \mathrm{Ca}^{2+}+\mathrm{Mg}^{2+}+4 \mathrm{HCO}_{3}{ }^{-}
\end{gathered}
$$

Recharge through an unsaturated zone and an aquifer containing a sufficient amount of carbonate will result in almost immediate calcite saturation by dissolution. The plot of $\mathrm{Ca} / \mathrm{Na}$ and $\mathrm{Mg} / \mathrm{Ca}$ (Figure 3a) shows that the increase of $\mathrm{Ca}$ and $\mathrm{Mg}$ is synchronous, suggesting that the above geochemical reactions occur, Equations (2)-(4). Meanwhile, the dissolution of carbonates always results in an increase in $\mathrm{Ca} / \mathrm{Na}$ or $\mathrm{Mg} / \mathrm{Na}$ and the dissolution of silicates results in a decrease in $\mathrm{Ca} / \mathrm{Na}$ or $\mathrm{Mg} / \mathrm{Na}[45,46]$. The endmember for dissolution of silicates is commonly defined as a milligram equivalent ratio of $<2$ (moral ratio of $<1$ ) for $\mathrm{Ca} / \mathrm{Na}$ and of $<1$ for $\mathrm{Mg} / \mathrm{Na}$ [46] and the dissolution of carbonate (including dolomite) always results in high ratios of $\mathrm{Ca} / \mathrm{Na}$ and $\mathrm{Mg} / \mathrm{Na}$. The results reflect a mixed influence of silicate and carbonate rock weathering (Figure 3a). When Sr concentrations in silicates are relatively lower than that in carbonates [12], the dissolution of silicates results in a low concentration of $\mathrm{Sr}$ in groundwater (Figure $3 \mathrm{~b}$ ). Figure 4 shows that the $\mathrm{Mg} / \mathrm{Ca}$ ratios (milligram equivalent ratio) range from 0.68 to 1.04 and increase with the groundwater age. When groundwater is over-saturated with respect to calcite, the subsequent dissolution of carbonate along the flow path originates from incongruent dissolution involving concomitant precipitation and the dissolution of carbonate minerals [12,47]. This suggests that the incongruent dissolution may be involved as follows:

$$
\mathrm{Ca}^{2+}+\mathrm{CaMg}\left(\mathrm{CO}_{3}\right)_{2} \rightarrow 2 \mathrm{CaCO}_{3}+\mathrm{Mg}^{2+}
$$
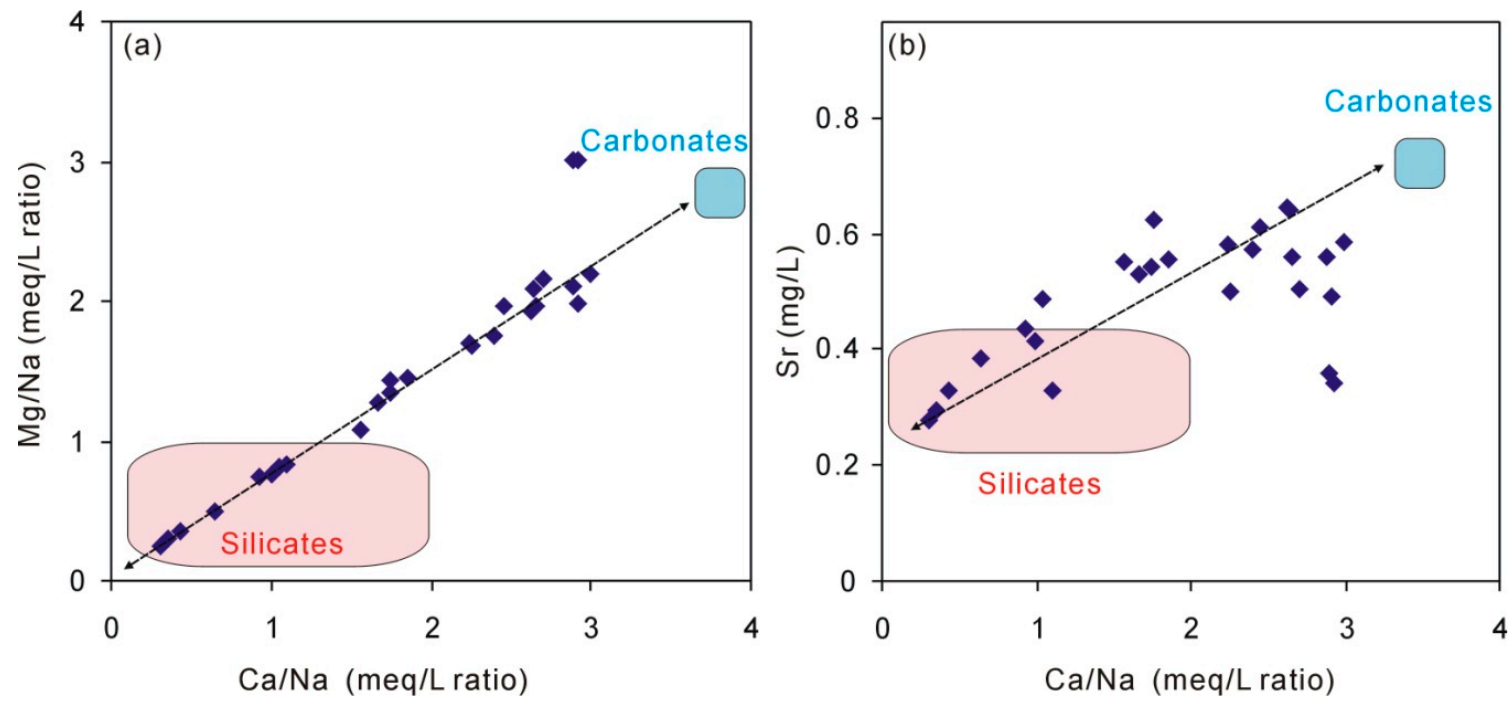

Figure 3. Plot of groundwater $\mathrm{Ca} / \mathrm{Na}$ and $\mathrm{Mg} / \mathrm{Na}(\mathbf{a})$ and plot of $\mathrm{Sr}$ concentration and $\mathrm{Ca} / \mathrm{Na}(\mathbf{b})$.

The groundwater ${ }^{87} \mathrm{Sr} /{ }^{86} \mathrm{Sr}$ ratios ranged from 0.710677 to $0.712319(\mathrm{n}=14)$ with an average of 0.711207. The ${ }^{87} \mathrm{Sr} /{ }^{86} \mathrm{Sr}$ ratios for carbonate extracted from loess by $0.5 \mathrm{M}$ HAc and $1 \mathrm{M} \mathrm{HAc} \mathrm{ranged}$ from 0.710329 to 0.711085 . The coincidence of ${ }^{87} \mathrm{Sr} /{ }^{86} \mathrm{Sr}$ ratios for carbonate and groundwater (Figure 5) suggests that the groundwater $\mathrm{Ca}+\mathrm{Mg}$ mainly originated from the dissolution of carbonate rather than the dissolution of calcium-containing plagioclase because further dissolution of calcium-containing plagioclase would increase the ${ }^{87} \mathrm{Sr} /{ }^{86} \mathrm{Sr}$ ratios [27]. Because there is very little $\mathrm{Sr}$ in albite, about 20 to 170 times less than oligoclase, labradorite, and anorthite [48], the dissolution of albite would not change 
the ${ }^{87} \mathrm{Sr} /{ }^{86} \mathrm{Sr}$ ratios of groundwater (Figure 5), which remain constant. The groundwater ${ }^{87} \mathrm{Sr} /{ }^{86} \mathrm{Sr}$ ratios suggest that the dissolution of calcium-containing plagioclase is little.

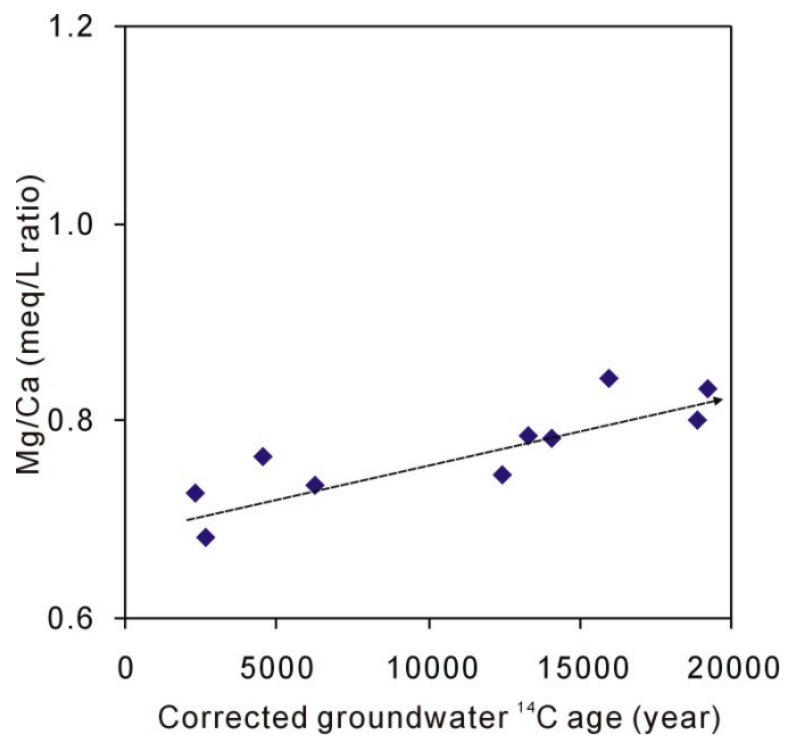

Figure 4. Plot of corrected groundwater ${ }^{14} \mathrm{C}$ ages and $\mathrm{Mg} / \mathrm{Ca}$ ratios.

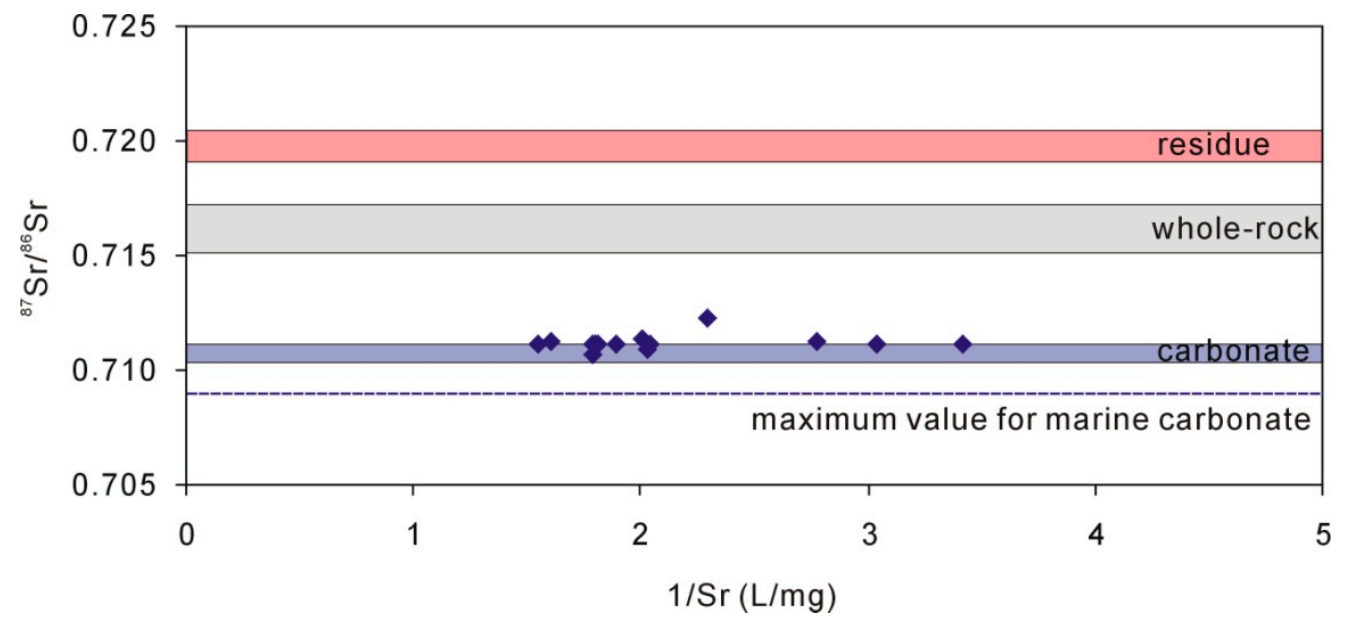

Figure 5. Groundwater ${ }^{87} \mathrm{Sr} /{ }^{86} \mathrm{Sr}$ ratios compared with carbonate minerals, whole-rock (loess), and residue after dissolution of 1-M HAc.

In the Loess Plateau, there were both C3 and C4 plants during the past 2.4 Ma [19], and there was $10 \%$ to $20 \% \mathrm{C} 4$ vegetation in the Xifeng Loess tableland, resulting in $\delta^{13} \mathrm{C}$ of soil $\mathrm{CO}_{2}$ of $-21.6 \%$ o to $-20.2 \%$ o [39]. Meanwhile, the $\delta^{13} \mathrm{C}$ values of loess carbonate range from $-8.3 \%$ o to $-3.3 \%$ o (Table 4 ). The dissolution of carbonates by soil $\mathrm{CO}_{2}$ would directly result in $\delta^{13} \mathrm{C}$ values of groundwater ranging from $-15.0 \%$ o to $-11.8 \%$ o through carbonates dissolution, Equations (2)-(4), indicated as (1) in Figure 6. However, the later carbon exchange between groundwater DIC (mainly $\mathrm{HCO}_{3}$ ) and soil $\mathrm{CO}_{2}$ (as (2) in Figure 6), and between groundwater DIC and carbonates in loess (as (3) in Figure 6) would change the groundwater $\delta^{13} \mathrm{C}$ values $(-9.6 \%$ o to $-8.1 \%$ o). In addition, there is no carbon production during the dissolution of albite except for soil $\mathrm{CO}_{2}$, Equation (1), i.e., the carbon in $\mathrm{HCO}_{3}$ is all from soil $\mathrm{CO}_{2}$. These complicated processes make the quantitative interpretation of groundwater $\delta^{13} \mathrm{C}$ more difficult.

Although the dissolution rate of albite is significantly less than that of calcium-containing plagioclase [49], the groundwater $\mathrm{Na}$ is mainly from the dissolution of albite, and the $\mathrm{Ca}+\mathrm{Mg}$ is from the dissolution of carbonate. This is mainly attributed to the saturation of calcite and dolomite, which has limited further dissolution of carbonate and calcium-containing plagioclase [37]. In addition, the 
times for groundwater residence are relatively long (220 to 19,220 year) and there is sufficient time for albite to dissolve.

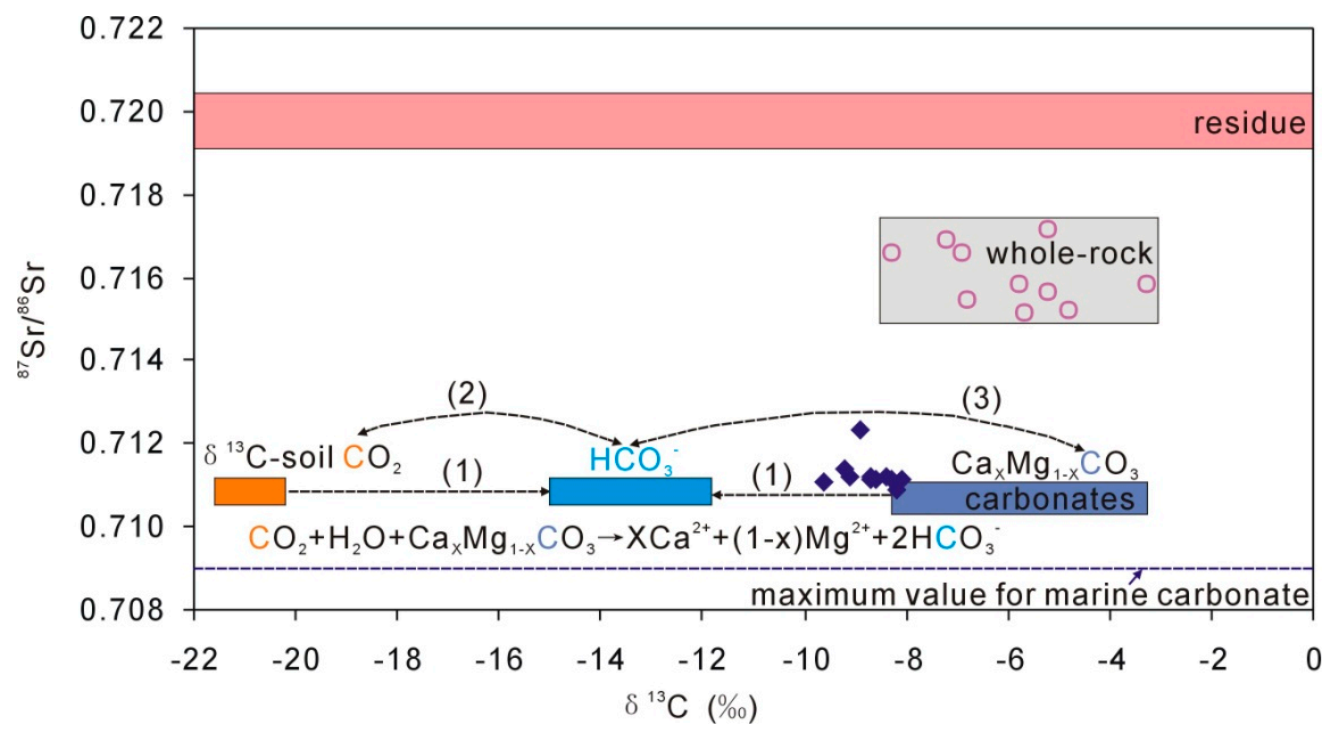

Figure 6. Plot of ${ }^{87} \mathrm{Sr} /{ }^{86} \mathrm{Sr}$ and $\delta^{13} \mathrm{C}$ for multiple endmembers in the loess aquifer. The blue diamonds present groundwater DIC (mainly as $\mathrm{HCO}_{3}$ ). Geochemical processes, as indicated (1), (2), and (3) are discussed in the text.

Loess contains materials like clay minerals [22] and organic matter [50], which can sorb chemicals. The cation exchange capacity (CEC) of a soil in meq $/ \mathrm{kg}$ is used to assess the adsorbents in soils and aquifers [4]. An empirical formula which relates the CEC to the percentages of clay $(<2 \mu \mathrm{m})$ and organic carbon (OC) at near neutral $\mathrm{pH}$ given by Breeuwsma et al. [51] is used to calculate the CEC of loess in the study area:

$$
\text { CEC }(\mathrm{meq} / \mathrm{kg})=500 \text { clay }+1500 \text { OC }
$$

In the study area, the average percentage of clay is $8.3 \%$ [21] and the OC is $0.35 \%$ [50]. Therefore, the average CEC is expected to be $47 \mathrm{meq} / \mathrm{kg}$. The average water content in loess is $20 \%$ for the unsaturated zone and 23\% for the saturated zone [21], and therefore the CEC for pore water is expected to be 204 to $235 \mathrm{meq} / \mathrm{L}$. Groundwater contains less than $6.2 \mathrm{meq} / \mathrm{L}$ cations in the study area, more than 30 times less than the amount of cations located on the exchanger. The principle factor influencing the absorption affinity of cations is valence. The following are the ions in decreasing adsorption affinity: $\mathrm{Ca}^{2+}=\mathrm{Mg}^{2+}>\mathrm{Na}^{+}[4,8]$. Therefore, in this neutral soil, the cation exchange can be involved:

$$
\begin{aligned}
& 2 \mathrm{NaX}+\mathrm{Ca}^{2+} \rightarrow \mathrm{CaX}_{2}+2 \mathrm{Na}^{+} \\
& 2 \mathrm{NaX}+\mathrm{Mg}^{2+} \rightarrow \mathrm{MgX}_{2}+2 \mathrm{Na}^{+}
\end{aligned}
$$

During cation exchange, the total cations (as meq/L) would not change. Figure 7 shows that when $\mathrm{Na}$ concentrations increase with time, the $\mathrm{Ca}+\mathrm{Mg}$ concentrations decrease. Meanwhile, the total concentrations $(\mathrm{Ca}+\mathrm{Mg}+\mathrm{Na})$ have not changed, suggesting that cation exchange between $\mathrm{Ca}+\mathrm{Mg}$ and $\mathrm{Na}$ has been involved in the loess aquifer and contributes additional $\mathrm{Na}$ in groundwater. 

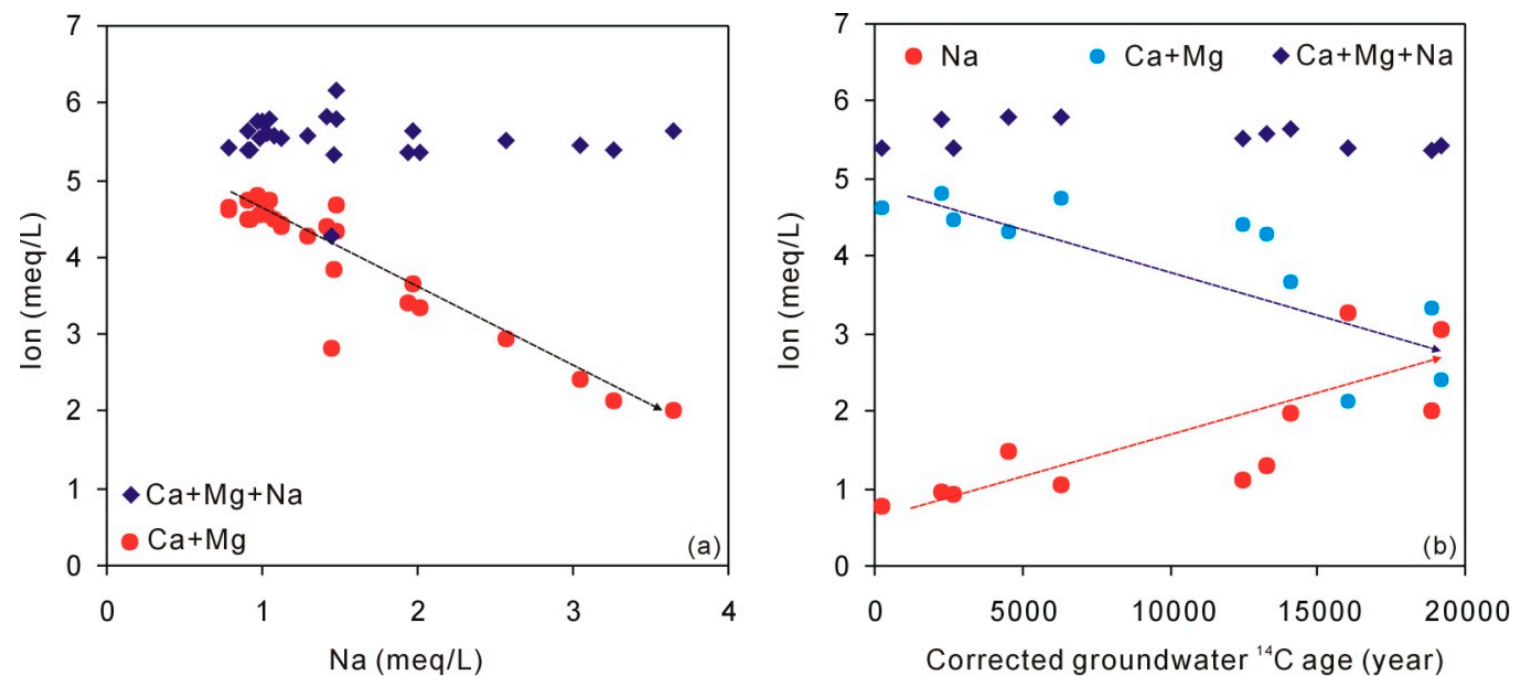

Figure 7. Plot of groundwater $\mathrm{Na}$ against $\mathrm{Ca}+\mathrm{Mg}$ and $\mathrm{Ca}+\mathrm{Mg}+\mathrm{Na}$ (a) and plot of corrected groundwater ${ }^{14} \mathrm{C}$ age against $\mathrm{Na}, \mathrm{Ca}+\mathrm{Mg}$, and $\mathrm{Ca}+\mathrm{Mg}+\mathrm{Na}(\mathbf{b})$.

\section{Conclusions}

The analyses of ${ }^{87} \mathrm{Sr} /{ }^{86} \mathrm{Sr}$ of carbonate in the matrix help to determine the origin of groundwater $\mathrm{Ca}$ and $\mathrm{Mg}$ in a complex aquifer (silicate and carbonate both exist). On the basis of the comparison of ${ }^{87} \mathrm{Sr} /{ }^{86} \mathrm{Sr}$ concentrations between groundwater and carbonate, groundwater $\mathrm{Ca}$ and $\mathrm{Mg}$ mainly originated from the dissolution of carbonate, but $\mathrm{Na}$ originated from the dissolution of albite. Meanwhile, there are cation exchanges between $\mathrm{Ca}+\mathrm{Mg}$ and $\mathrm{Na}$, resulting in $\mathrm{Na}$ concentration increases and $\mathrm{Ca}+\mathrm{Mg}$ concentration decreases in groundwater. $\mathrm{Cl}$ and $\mathrm{SO}_{4}$ originated from atmospheric deposition. This study is important to the understand of the origin of the major ions in groundwater and the geochemical processes in silicate-carbonate aquifers.

Author Contributions: Conceptualization, T.H.; methodology, B.M. and T.H.; investigation, T.H. and B.M.; writing, T.H.

Funding: The work is supported by the National Natural Science Foundation of China, grant numbers 41672254 and 41877207, and the Youth Innovation Promotion Association CAS, grant number 2018087.

Acknowledgments: The authors thank Zhenbin Li for his help in field sampling and Yiman Li for her help in conducting the experiment. The authors also wish to express their appreciation to the editor and three anonymous reviewers whose detailed comments were very helpful in improving the clarity and focus of the manuscript.

Conflicts of Interest: The authors declare no conflict of interest.

\section{References}

1. Shiklomanov, I.A.; Rodda, J.C. World Water Resources at the Beginning of the 21st Century; Cambridge University Press: Cambridge, UK, 2003; pp. 1-18.

2. De Vries, J.J.; Simmers, I. Groundwater recharge: An overview of processes and challenges. Hydrogeol. J. 2002, 10, 5-17. [CrossRef]

3. Kemper, K.E. Groundwater from development to management. Hydrogeol. J. 2004, 12, 3-5. [CrossRef]

4. Appelo, C.A.J.; Postma, D. Geochemistry, Groundwater and Pollution, 2nd ed.; A. A. Balkema Publishers: Amsterdam, The Netherlands, 2005; pp. 1-634.

5. Edmunds, W.M. Limits to the availability of groundwater in Africa. Environ. Res. Lett. 2012, 7, 021003. [CrossRef]

6. Edmunds, W.M. Geochemistry's vital contribution to solving water resource problems. Appl. Geochem. 2009, 24, 1058-1073. [CrossRef]

7. Huang, T.; Pang, Z.; Li, J.; Xiang, Y.; Zhao, Z. Mapping groundwater renewability using age data in the Baiyang alluvial fan, NW China. Hydrogeol. J. 2017, 25, 743-755. [CrossRef] 
8. Shen, Z.; Zhu, Y.; Zhong, Y. Hydrogeochemistry; Geological Publishing House: Beijing, China, 1993; pp. 1-189.

9. Marcus, Y.; Kertes, A.S. Ion Exchange and Solvent Extraction of Metal Complexes; Wiley Interscience: New York, NY, USA, 1969; pp. 1-1037.

10. Salifu, M.; Aiglsperger, T.; Hällström, L.; Martinsson, O.; Billström, K.; Ingri, J.; Dold, B.; Alakangas, L. Strontium $\left({ }^{87} \mathrm{Sr} /{ }^{86} \mathrm{Sr}\right)$ isotopes: A tracer for geochemical processes in mineralogically-complex mine wastes. Appl. Geochem. 2018, 99, 42-54. [CrossRef]

11. Tipper, E.T.; Bickle, M.J.; Galy, A.; West, A.J.; Pomiès, C.; Chapman, H.J. The short term climatic sensitivity of carbonate and silicate weathering fluxes: Insight from seasonal variations in river chemistry. Geochim. Cosmochim. Acta 2006, 70, 2737-2754. [CrossRef]

12. McNutt, R.H. Strontium Isotopes. In Environmental Tracers in Subsurface Hydrology; Cook, P.G., Herczeg, A.L., Eds.; Kluwer Academic Publishers: New York, NY, USA, 2000; pp. 233-260.

13. Palmer, M.R.; Edmond, J.M. Controls over the strontium isotope composition of river water. Geochim. Cosmochim. Acta 1992, 56, 2099-2111. [CrossRef]

14. Han, G.; Liu, C.Q. Water geochemistry controlled by carbonate dissolution: A study of the river waters draining karst-dominated terrain, Guizhou Province, China. Chem. Geol. 2004, 204, 1-21. [CrossRef]

15. Shand, P.; Darbyshire, D.P.F.; Love, A.J.; Edmunds, W.M. Sr isotopes in natural waters: Applications to source characterisation and water-rock interaction in contrasting landscapes. Appl. Geochem. 2009, 24, 574-586. [CrossRef]

16. Bickle, M.J.; Harris, N.B.W.; Bunbury, J.M.; Chapman, H.J.; Fairchild, I.J.; Ahmad, T. Controls on the ${ }^{87} \mathrm{Sr} /{ }^{86} \mathrm{Sr}$ Ratio of Carbonates in the Garhwal Himalaya, Headwaters of the Ganges. J. Geol. 2001, 109, 737-753. [CrossRef]

17. Yang, J.; Chen, J.; An, Z.; Shield, G.; Tao, X.; Zhu, H.; Ji, J.; Chen, Y. Variations in ${ }^{87} \mathrm{Sr} /{ }^{86} \mathrm{Sr}$ ratios of calcites in Chinese loess: A proxy for chemical weathering associated with the East Asian summer monsoon. Palaeogeogr. Palaeoclimatol. Palaeoecol. 2000, 157, 151-159. [CrossRef]

18. Chen, J.; Li, G.; Yang, J.; Rao, W.; Lu, H.; Balsam, W.; Sun, Y.; Ji, J. Nd and Sr isotopic characteristics of Chinese deserts: Implications for the provenances of Asian dust. Geochim. Cosmochim. Acta 2007, 71, 3904-3914. [CrossRef]

19. Yang, S.; Ding, Z.; Li, Y.; Wang, X.; Jiang, W.; Huang, X. Warming-induced northwestward migration of the East Asian monsoon rain belt from the last glacial maximum to the mid-Holocene. Proc. Natl. Acad. Sci. USA 2015, 112, 13178-13183. [CrossRef] [PubMed]

20. Zheng, Y.; Chen, J. Geochemistry of Stable Isotopes; Science Press: Beijing, China, 2000; pp. 193-217.

21. Huang, T.; Ma, B.; Pang, Z.; Li, Z.; Li, Z.; Long, Y. How does precipitation recharge groundwater in loess aquifers? Evidence from multiple environmental tracers. J. Hydrol. 2019. in revision.

22. Liu, T.S. Loess and the Environment; Science Press: Beijing, China, 1985; pp. 1-481.

23. Geng, A.; Wen, Q. Some geochemical characteristics of carbonates in Luochuan loess, Shaanxi Province. Geochimica 1988, 17, 267-275.

24. Ning, Y.; Liu, W.; An, Z. Variation of soil $\Delta \delta 13 \mathrm{C}$ values in Xifeng loess-paleosol sequence and its paleoenvironmental implication. Chin. Sci. Bull. 2006, 51, 1350-1354. [CrossRef]

25. Qu, H. Assessment of Groundwater Resources in the Arid and Semiarid Land of China; Science Press: Beijing, China, 1991; pp. 1-457.

26. Sheng, X.; Yang, J.; Li, C.; Chen, J.; Tao, X. A method for separation of calcite and dolomite in loess and sedimentary rocks. Rock Miner. Anal. 2000, 19, 264-267.

27. Yokoo, Y.; Nakano, T.; Nishikawa, M.; Quan, H. Mineralogical variation of Sr-Nd isotopic and elemental compositions in loess and desert sand from the central Loess Plateau in China as a provenance tracer of wet and dry deposition in the northwestern Pacific. Chem. Geol. 2004, 204, 45-62. [CrossRef]

28. Barta, G. Secondary carbonates in loess-paleosoil sequences: A general review. Cent. Eur. J. Geosci. 2011, 3, 129-146. [CrossRef]

29. Keith, M.L.; Weber, J.N. Carbon and oxygen isotopic composition of selected limestones and fossils. Geochim. Cosmochim. Acta 1964, 18, 1787-1816. [CrossRef]

30. Parkhurst, D.L.; Appelo, C.A.J. User's Guide to PHREEQC (Version 2)—A Compute Program for Speciation, Batch-Reaction, One-Dimensional Transport, and Inverse Geochemical Calculations; USGS: Reston, VA, USA, 1999; pp. 1-312. 
31. Herczeg, A.L.; Edmunds, W.M. Inorganic ions as tracers. In Environmental Tracers in Subsurface Hydrology; Cook, P.G., Herczeg, A.L., Eds.; Kluwer Academic Publishers: New York, NY, USA, 2000; pp. 31-78.

32. Hem, J.D. Study and Interpretation of the Chemical Characteristics of Natural Water; Water Supply Paper, no. 2254; US Geological Survey: Reston, VA, USA, 1985; pp. 1-264.

33. Allison, G.B.; Hughes, M.W. The use of environmental chloride and tritium to estimate total recharge to an unconfined aquifer. Aust. J. Soil Res. 1978, 16, 181-195. [CrossRef]

34. Edmunds, W.M.; Walton, N.R.G. A geochemical and isotopic approach to recharge evaluation in semi-arid zones-Past and present. In Arid-Zone Hydrology: Investigations with Isotope Techniques, Proceeding of Advisory Group Meeting; Fontes, J.C., Ed.; IAEA: Vienna, Austria, 1980; pp. 47-68.

35. Eriksson, E.; Khunakasem, V. Chloride concentration in groundwater, recharge rate and rate of deposition of chloride in the Israel Coastal Plain. J. Hydrol. 1969, 7, 178-197. [CrossRef]

36. Wood, W.W.; Sanford, W.E. Chemical and isotopic methods for quantifying groundwater recharge in a regional, semiarid environment. Ground Water 1995, 33, 458-468. [CrossRef]

37. Mazor, E. Chemical and Isotopic Groundwater Hydrology, 3rd ed.; Dekker: New York, NY, USA, 2004; pp. 1-453.

38. Edmunds, W.M.; Ma, J.; Aeschbach-Hertig, W.; Kipfer, R.; Darbyshire, D.P.F. Groundwater recharge history and hydrogeochemical evolution in the Minqin Basin, North West China. Appl. Geochem. 2006, 21, 2148-2170. [CrossRef]

39. Huang, T.; Pang, Z.; Liu, J.; Ma, J.; Gates, J. Groundwater recharge mechanism in an integrated tableland of the Loess Plateau, northern China: Insights from environmental tracers. Hydrogeol. J. 2017, 25, 2049-2065. [CrossRef]

40. Huang, T.; Pang, Z. Estimating groundwater recharge following land-use change using chloride mass balance of soil profiles: A case study at Guyuan and Xifeng in the Loess Plateau of China. Hydrogeol. J. 2011, 19, 177-186. [CrossRef]

41. Feth, J.H. Chloride in Natural Continental Water: A Review; Water Supply Paper, no. 2176; US Geological Survey: Reston, VA, USA, 1981; pp. 1-30.

42. The Acid Deposition Monitoring Network in East Asia (EANET). Available online: http://www.eanet.asia (accessed on 12 October 2018).

43. Wang, T.; Wang, P.; Theys, N.; Tong, D.; Hendrick, F.; Zhang, Q.; van Roozendael, M. Spatial and temporal changes in $\mathrm{SO}_{2}$ regimes over China in the recent decade and the driving mechanism. Atmos. Chem. Phys. 2018, 18, 18063-18078. [CrossRef]

44. Huang, T.; Fan, Y.; Long, Y.; Pang, Z. Quantitative calculation for the contribution of acid rain to carbonate weathering. J. Hydrol. 2019, 568, 360-371. [CrossRef]

45. Gaillardet, J.; Dupré, B.; Louvat, P.; Allègre, C.J. Global silicate weathering and $\mathrm{CO}_{2}$ consumption rates deduced from the chemistry of large rivers. Chem. Geol. 1999, 159, 3-30. [CrossRef]

46. Petelet-Giraud, E.; Luck, J.M.; Othman, D.B.; Joseph, C.; Négrel, P. Chemical and isotopic fingerprinting of small ungauged watershed: How far the hydrological functioning can be understood? Comptes Rendus Geosci. 2016, 348, 379-386. [CrossRef]

47. Bishop, P.K.; Smalley, P.C.; Emery, D.; Dickson, J.A.D. Strontium isotopes as indicators of the dissolving phase in a carbonate aquifer: Implications for ${ }^{14} \mathrm{C}$ dating of groundwaters. J. Hydrol. 1994, 154, 301-321. [CrossRef]

48. Giletti, B.J.; Casserly, J.E.D. Strontium diffusion kinetics in plagioclase feldspars. Geochim. Cosmochim. Acta 1994, 58, 3785-3793. [CrossRef]

49. Welch, W.S.A.; Ullman, J. Feldspar dissolution in acidic and organic solutions: Compositional and $\mathrm{pH}$ dependence of dissolution rate. Geochim. Cosmochim. Acta 1996, 60, 2939-2948. [CrossRef]

50. Rao, Z.; Zhang, X.; Xue, S.; Xu, Y.; Liu, X. Primary organic carbon isotopic study result of Xifeng loess/red clay profile. Quat. Sci. 2012, 32, 825-827.

51. Breeuwsma, A.; Wösten, J.H.M.; Vleeshouwer, J.J.; van Slobbe, A.M.; Bouma, J. Derivation of land qualities to assess environmental problems from soil surveys. Soil Sci. Soc. Am. J. 1986, 50, 186-190. [CrossRef]

(C) 2019 by the authors. Licensee MDPI, Basel, Switzerland. This article is an open access article distributed under the terms and conditions of the Creative Commons Attribution (CC BY) license (http://creativecommons.org/licenses/by/4.0/). 